\title{
Store Image: Toward a Conceptual Model PART 1
}

\author{
RONEL DU PREEZ \\ ELIZABETH VISSER \\ HESTER JANSE VAN NOORDWYK \\ Department of Industrial Psychology \\ Stellenbosch University \\ South Africa \\ Correspondence to: Ronel du Preez \\ e-mail: rdp@sun.ac.za
}

\begin{abstract}
The lack of a universal definition and conceptual model of store image guided the aims for this research, namely to 1) delineate the underlying structure of the store image construct; 2) formulate a definition of store image; and 3) develop a model of the underlying theoretical structure of store image. An in-depth literature review was done to specify the domain and to delineate the underlying structure of this construct. The knowledge gained was incorporated into the model of apparel store image that served as point of departure for the development of a scale to measure the importance of apparel store image dimensions.
\end{abstract}

Keywords: store image, dimensions, apparel, conceptual model, multi-dimensional

This article is the first in a series of three focussing on the multidimensional nature of the store image and the complexity of measuring this construct. Although the literature cited is generic, apparel store image was central to the investigation. The theoretical underpinnings of store image are discussed in Part 1 followed by an overview of scale development in Part 2 . Part 3 reports the empirical testing of the Apparel Store Image Scale.

What is store image? This question has been the focus of various research endeavours. Martineau (1958, p. 47), in his seminal study on store image, first defined store image as "...the way in which the store is defined in the shopper's mind, partly by its functional qualities and partly by an aura of psychological attributes". Lindquist (1974-1975, p. 31) concluded that store image is "...complex by nature and consists of a combination of tangible or functional factors and intangible or psychological factors that a consumer perceives to be present". According to the literature most definitions stress that store image is the consumer's perception of a store, based on a set of salient attributes (Bloemer \& De Ruyter, 1998; Faircloth, Capella \& Alford, 2001; James, Durand \& Dreves, 1976; Jin \& Kim, 2003; Osman, 1993). However, researchers contend that the definition of store image is more than the factual description of characteristics; it also describes the interaction among characteristics (Amirani \& Gates, 1993; Dichter, 1985; Oxenfeldt, 1974-1975). Zimmer and Golden (1988) as well as Keaveney and Hunt (1992) referred to the gestalt nature of the store image construct. The term gestalt is defined as "...the idea that the individual's perception of any object incorporates innumerable bits of separate information that are combined in such a manner that the end result of the integration of inputs amounts to more than the sum of its constituent parts" (Chowdhary, Reardon \& Srivastava, 1998, p. 73).

Why is store image important? The contextualisation of store image within the scope of corporate personality, corporate identity and corporate image has been reported extensively by scholars such as Kennedy (1977), Dowling (1986), Abratt (1989), Markwick and Fill (1997), Varley (2005) and Stuart (1999). The broad context of corporate branding was established by investigating the interplay between corporate strategy, culture, identity and image as reported in Visser, Du Preez and Janse van Noordwyk (2006). The relevance of store image within this context, and more specifically the context of the retail store brand, was discussed. Visser et al. (2006, p. 51) proposed an integrated model of store choice and retail marketing strategy by adapting Monroe and Guiltinan's model of store choice (in Assael, 1992, p. 630) and combining it with Davidson, Sweeney and Stampfl's model (in Terblanché, 1998, p. 106). This proposed model positions store image as a critical variable in apparel store choice. It also indicates the interaction between the uncontrollable and controllable consumer needs and the position of retailing in the market as well as in the integrated marketing strategy. Against this broad background the construct of store image was further investigated in order to specify the domain and to delineate the underlying structure thereof.

It is evident that a universal and generally accepted definition of store image (pertaining to specifically the dimensions of store image) is still lacking. Academic debates concerning the theoretical underpinnings of store image further complicate matters (Chowdhary et al., 1998). If researchers employ different definitions of a construct, comparison and accumulation of research findings are hampered, resulting in an inability to develop syntheses of existing knowledge and to develop scientifically sound measuring instruments. These are prerequisites for driving research and advancing theory building (DeVellis, 2003; Hair, Black, Babin, Anderson \& Tatham, 2006; Netemeyer, Bearden \& Sharma, 2003). There is little evidence of these issues in store image research. The overall objectives of this article series focus on the definition of store image, the development of a measurement scale and the testing thereof in an apparel retail environment.

The aims of this paper are to

- specify the store image domain from existing store image literature;

- develop a conceptual model of store image and related consumer behaviour variables;

- delineate the underlying structure (dimensions and subdimensions) of the store image construct;

- formulate a definition of store image; and

- develop a model of the underlying theoretical structure of apparel store image. 


\section{STORE IMAGE DOMAIN SPECIFICATION}

To specify the domain of store image, consumer behaviour variables in store image research were identified. Firstly, consumer behaviour variables employed as independent variables in store image research will be highlighted. Secondly, a summary will be given of research in which the relationship between store image perception and dependent consumer behaviour variables was investigated. This section spans empirical research of more than three decades but does not profess to be inclusive of all related literature.

Results from studies on the relationship between demographic variables (age, gender, level of education, occupation, residence, income level, marital status and number of children) and perceived store image were marked by contradicting findings (Chowdhary, 1999; Gehrt \& Yan, 2004; Hyllegard, Eckman, Descals \& Borja, 2005; Moye \& Giddings, 2002; Oates, Shufeldt \& Vaught, 1996; Odekerken-Schröder, De Wulf, Kasper, Kleijnen, Hoekstra \& Commandeur, 2001; Paulins \& Geistfeld,
2003; Williams \& Slama, 1995). Consequently no definitive conclusions can be drawn about the influence of demographic variables on the perceived importance of store image.

Initial support for the relationship between store image perception and lifestyle as a psychographic variable has been found, whether directly or indirectly. Shim and Kotsiopulos (1992) indicated that shopping orientations act as mediator in the relationship between lifestyle and store image perception. The relationship between store image and other psychographic variables (i.e. environmental disposition and values), however, was only supported by isolated findings (Erdem, Oumlil \& Tuncalp, 1999; Grossbart, Hampton, Rammohan \& Lapidus, 1990).

Only a few studies investigated the influence of socio-cultural variables (family life cycle, social class, subculture and specifically culture) on store image. Two studies suggested a relationship between culture and the perceived importance of store image. Differences in ethnicity (Kim \& Han, 2000) and

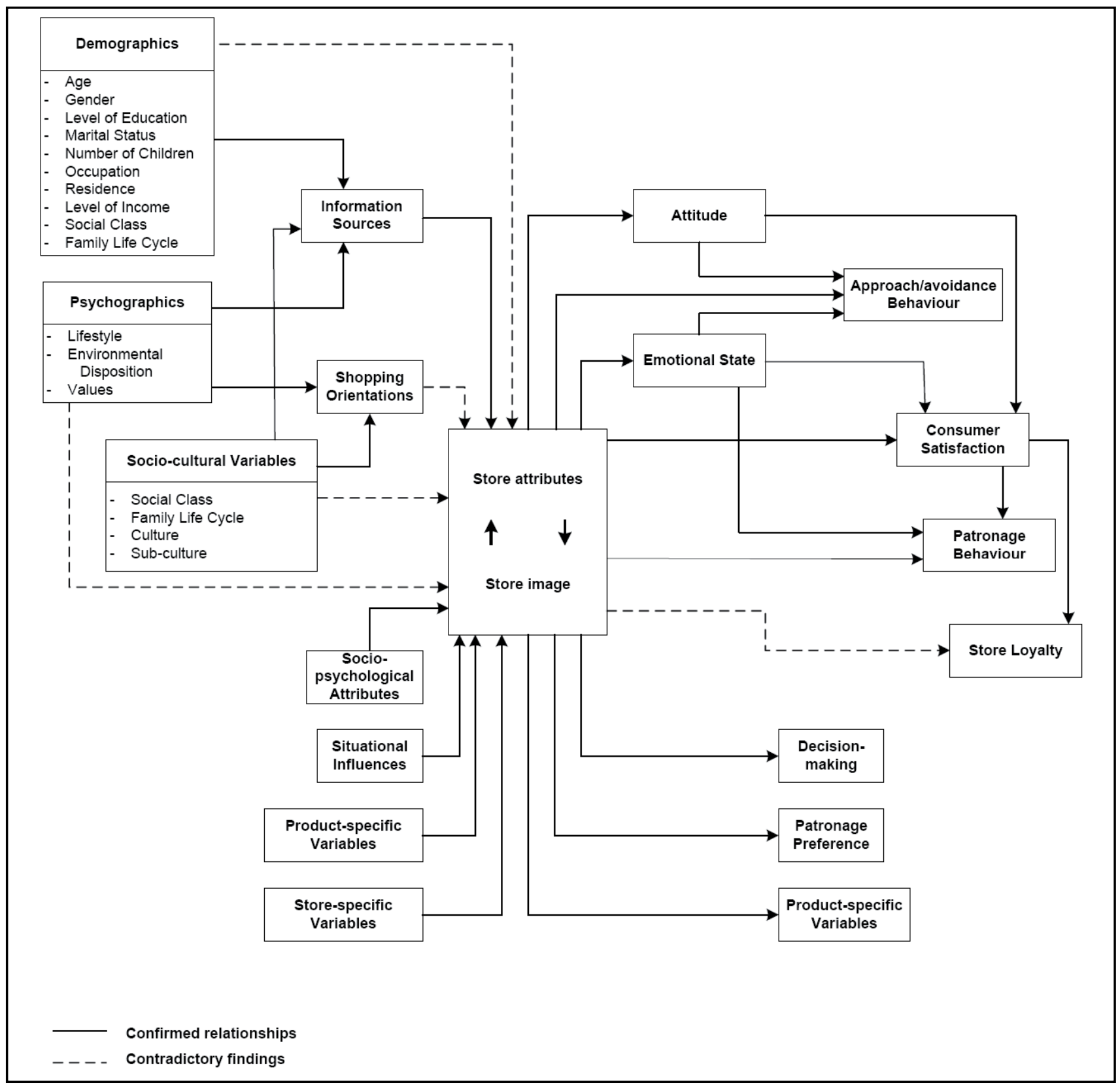

FIGURE 1

Proposed conceptual theoretical model of store image and related consumer behaviour variables 
root culture (Van de Velde, Pelton, Turnbull Caton \& Byrne, 1996) were reported. Shim and Kotsiopulos (1992) found that socio-cultural variables had an indirect relationship with store image perception mediated by shopping orientation. Contrary to Janse van Noordwyk (2002) who reported differences between subcultural groups based on population group and their perceptions of store image, Gehrt and Yan (2004) indicated that ethnicity did not influence the perceived importance of retail attributes.

The relationship between socio-psychological variables (especially self-image and body cathexis) and perceived store image was investigated. Shim, Kotsiopulos and Knoll (1990) found that men with different body types varied regarding their satisfaction with store attributes. Other researchers (Graeff 1996; Quester, Karunaratna \& Goh, 2000; Hogg, Cox \& Keeling, 2000; Jamal \& Goode, 2001; Thompson \& Chen, 1998) identified a positive relationship between self-image, brand image and brand perceptions, which can be applied to the perceptions of store image. Graeff (1996) stated that self-image and brand image congruence serves as an evaluative criterion in the attitude towards a brand. The results from these studies provide unequivocal support for the importance of self-image congruence with store image.

Studies provided initial support for a relationship between information sources and store image perception (Faircloth et al., 2001; Jin \& Kim, 2003; Kliatchko, 2005; Osman, 1993; Shim \& Kotsiopulos, 1992; Williams \& Slama, 1995). Similarly, support was found for the relationship between situational influences (e.g. gift shopping, time pressure, urgent purchases and usage situations) and the perception of store image (Gehrt \& Yan, 2004; Mattson, 1982; Moye \& Kincade, 2002; Van Kenhove, De Wulf \& Van Waterschoot, 1999). However, the specific situational influence variables included within each study differed significantly.

The relationship between shopping orientation and store image perception was more conclusive although the shopping orientation groups that were identified in specific studies differed (Morschett, Swoboda \& Foscht, 2005; Moye \& Giddings, 2002; Moye \& Kincade, 2002; Shim \& Kotsiopulos, 1992; Visser \& Du Preez, 2001). The results of Shim and Kotsiopulos (1992) indicated that shopping orientations predict the importance of store attributes. In contrast, Morschett et al. (2005) found that consumers' shopping motives did not impact on their perception of store attributes. Results indicated that shopping motives had an impact on consumers' attitudes towards retailers. Consistent support was found for the relationship between store image perception and product-specific variables (Amine \& Cadenat, 2003; Porter \& Claycomb, 1997; Collins-Dodd \& Lindley, 2003) as well as store-specific variables (Joyce \& Lambert, 1996; Mitchell \& Kiral, 1998; Moore \& Carpenter, 2006; Paulins \& Geistfeld, 2003; Solgaard \& Hansen, 2003; Shim \& Kotsiopulos, 1992). Research on product-specific variables refers to brand image and label brand quality while store-specific variables refer to store type.

Various studies reported relationships between dependent consumer behaviour variables and store image perception. Results from these studies are less contradictory. Although only a few studies investigated the relationship between store image perception and attitude (Ajzen, 1988; Ajzen \& Fishbein, 2004) and emotional state (Grace \& O'Cass, 2005; Solomon, 2002), results are indicative of the influence of store image perception on these variables. Research provides evidence of the relationship between perceived store image and decision making, although the types of decision vary greatly (Faircloth, et al., 2001; Jin \& Kim, 2003; Osman, 1993; Ward, Bitner \& Barnes, 1992). Strong support was found for the relationship between store image perception and both patronage preference
(Amirani \& Gates, 1993; Paulins \& Geistfeld, 2003; Thang \& Tan, 2003) and approach/avoidance behaviour. However, research indicated that in some instances the relationship between store image perception and approach/avoidance behaviour was mediated by emotional state (Donovan \& Rossiter, 1982; Moye \& Giddings, 2002; Ward et al., 1992).

Support was found for the influence of perceived store image on patronage behaviour (Baker, Parasuraman, Grewal \& Voss, 2002; Grace \& O'Cass, 2005; Newberry, Klemz \& Boshoff, 2003) as well as on store satisfaction (Bloemer \& De Ruyter, 1998; Gómez, McLaughlin \& Wittink, 2003; Koo, 2003; Miranda, Kònja \& Havrila, 2005). Research on the relationship between perceived store image and store loyalty concluded with contradicting findings. Chang and Tu (2005), Koo (2003) and Miranda et al. (2005) reported a direct positive relationship between store image perception and store loyalty. Only partial support for this relationship was found by Odekerken-Schröder et al. (2001) whereas Bloemer and De Ruyter's (1998) study found an indirect positive relationship. Lastly, the influence of store image perception on product-specific variables was supported, although the specific attributes included in the literature varied (Collins-Dodd \& Lindley, 2003; Semeijn, Van Riel \& Ambrosini, 2003; Stern, Zinkhan \& Jaju, 2001; Varley, 2005).

The knowledge gained from this review of research was amalgamated into a conceptual theoretical model (see Figure 1) delineating proposed relationships between store image and related consumer behaviour variables. Central to this model is the interaction between store attributes and store image, where store image formation is based on consumers' perceptions of all the attributes associated with a store (Faircloth et al., 2001; Jin \& Kim, 2003; Osman, 1993). The model further delineates the influence of consumer behaviour and related variables on

TABLE 1

Store image dimensions identified from the literature

\begin{tabular}{|c|c|}
\hline DIMENSION & DIMENSION NAMES INCLUDED FROM LITERATURE \\
\hline Atmosphere & $\begin{array}{l}\text { Activity dimension; Clean and spacious atmosphere; Music/ } \\
\text { aesthetics dimension; Store atmosphere; Store atmosphere } \\
\text { - aural; Store atmosphere - olfactory; Store atmosphere } \\
\text { - tactile; Store atmosphere - visual }\end{array}$ \\
\hline Convenience & $\begin{array}{l}\text { Accessibility; Congestion; Convenience; Convenience } \\
\text { (economic); Convenience - store location and mobility; } \\
\text { Convenient facilities; Errand shopping; Facility convenience; } \\
\text { In-store convenience and physical environment; Leisure } \\
\text { activities; Location; Location and convenience; Price; } \\
\text { Promotions/convenience; Proximity and familiarity; Service } \\
\text { convenience; Variety under one roof }\end{array}$ \\
\hline Facilities & $\begin{array}{l}\text { Appearance; Congestion; Convenient facilities; Facilities; } \\
\text { Facility convenience; Family shopping; Outside attractiveness; } \\
\text { Physical facilities; Sensory/layout dimension; Servicescape; } \\
\text { Service - store facilities; Store layout }\end{array}$ \\
\hline Institutional & Clientele; Institutional; Institutional factors \\
\hline Merchandise & $\begin{array}{l}\text { Brand name; Fabric; Fashionability; Fashion goods; Focused } \\
\text { shopping; Merchandise; Merchandise value; Merchandise } \\
\text { variety; Merchandising; Popularity; Price; Price and quality } \\
\text { aspects; Price competitiveness; Price/quality dimensions; } \\
\text { Products; Quality/reputation; Rich mix of commodities and } \\
\text { services; Status; Technical quality; Time/availability; Value; } \\
\text { Value-added service }\end{array}$ \\
\hline Promotion & $\begin{array}{l}\text { Advertising; Interest shopping; Promotion; Promotions; } \\
\text { Promotions/convenience; Sales and incentives }\end{array}$ \\
\hline $\begin{array}{l}\text { Sales } \\
\text { personnel }\end{array}$ & $\begin{array}{l}\text { Employee service; Functional quality; Personal interaction; } \\
\text { Personnel; Preference for salespeople; Relational quality; } \\
\text { Salesmanship; Salespeople service; Salesperson/service; } \\
\text { Service - sales associates attributes }\end{array}$ \\
\hline Service & $\begin{array}{l}\text { After-sales service; Complaint handling; Core service; } \\
\text { Credit; Credit facilities; Employee service; In-store service; } \\
\text { Merchandise; Merchandise requests; Post-transaction service; } \\
\text { Presence of related services; Rich mix of commodities and } \\
\text { services; Salespeople service; Salesperson service; Service; } \\
\text { Service convenience; Services; Service - sales associates } \\
\text { attributes; Service - store amenities; Service - store facilities; } \\
\text { Value-added service; Various store services }\end{array}$ \\
\hline
\end{tabular}




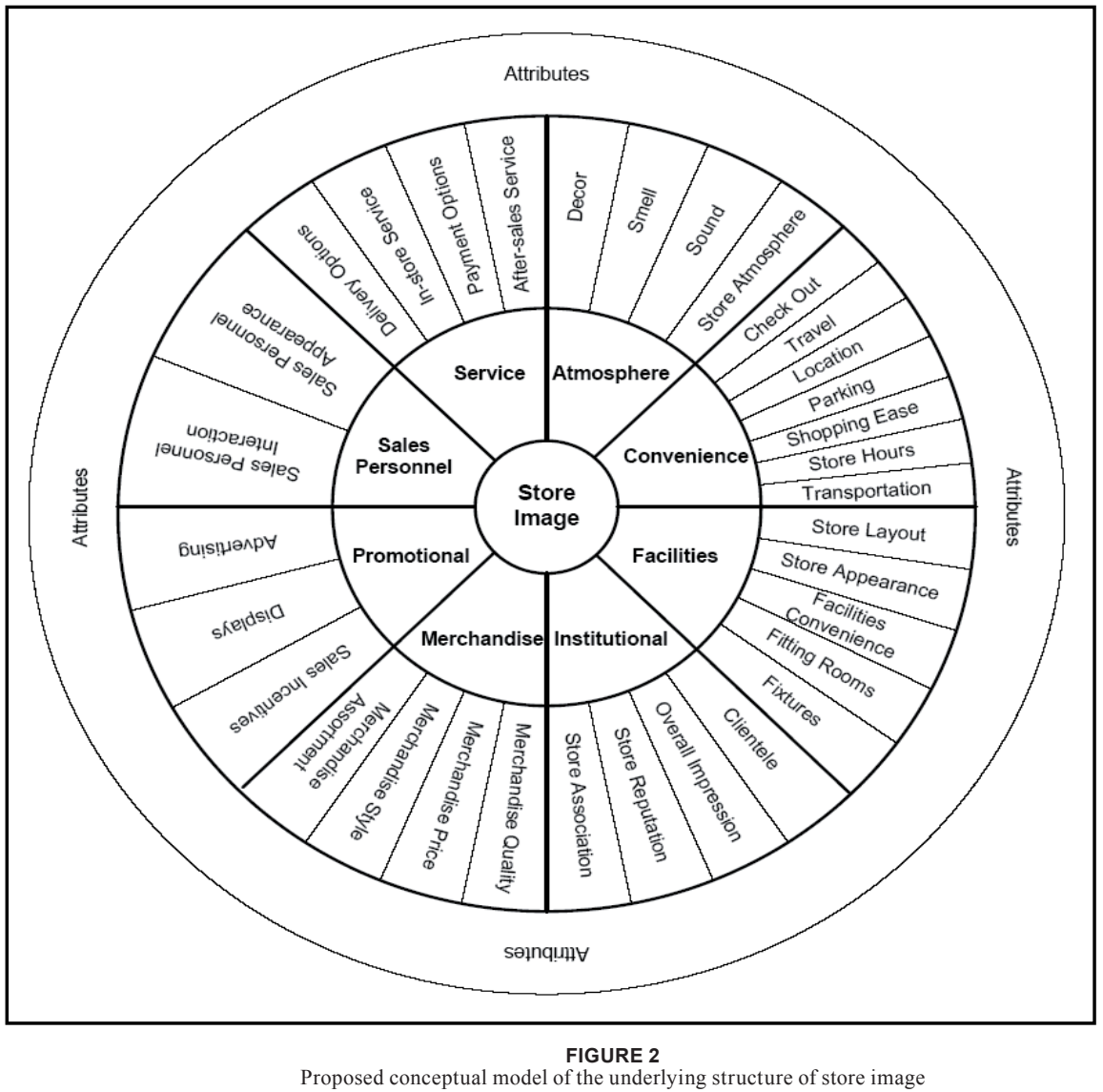

store image. Relationships that were supported by research findings are indicated with a solid line. Where results reported contradictory findings the relationships are presented by a broken line.

\section{UNDERLYING STRUCTURE OF STORE IMAGE: DIMENSIONS AND SUBDIMENSIONS}

Store image literature yielded a significant number of researchers who presented their view of the underlying structure (dimensions and subdimensions) of store image. However, it is evident that they did not consistently employ a similar underlying structure. The lack of a clear definition of store image is, therefore, further exacerbated by the absence of consensus on a set of universal store image dimensions (Amirani \& Gates, 1993; Burns, 1992). Those researchers who reported dimensions and subdimensions for store image employed various research methodologies to arrive at these structures, namely

- review of the literature (Cary \& Zylla, 1981; Grace \& O'Cass, 2005; Ko \& Kincade, 1997; Koo, 2003; Kotler, 19731974; Lumpkin, Greenberg \& Goldstucker, 1985; Manolis, Keep, Joyce \& Lambert, 1994; Odekerken-Schröder et al., 2001; Thang \& Tan, 2003; Terblanché \& Boshoff, 2004; Wong $\& \mathrm{Yu}, 2003)$

- qualitative research (Janse van Noordwyk, 2002; Lee \& Johnson, 1997; Visser et al., 2006; Zimmer \& Golden, 1988);

- quantitative research with the application of exploratory factor analysis (Bellenger, Robertson \& Greenberg, 1977; Bellizzi, Crowley \& Hasty, 1983; Chowdhary, 1999; Erdem et al., 1999; Huddleston, Ford \& Mahoney, 1990; Kim \& Jin, 2001; Marks, 1976; Moye \& Kincade, 2002; Sullivan, Savitt, Zheng \& Cui, 2002); and

- multiple discriminant analysis (Wong \& Teas, 2001).
For the purposes of this study it was imperative to take cognisance of the findings of these researchers. The process of identifying store image dimensions included several distinct phases. Firstly, store image dimensions were identified from literature, and secondly, these dimensions were refined to arrive at a final set of dimensions underpinning store image. This first phase employed a systematic process with several distinct stages that enabled the researchers to integrate the literature into a final set of store image dimensions, namely

- compiling a composite list of dimensions from the literature;

- identifying emerging dimensions;

- compiling a composite list of the subdimensions included within each dimension;

- grouping isolated dimensions with the identified dimensions based on a comparison of subdimensions; and

- compiling a set of dimensions to be subjected to refinement to arrive at a final set of dimensions.

After compiling a composite list of all store image dimensions (stage 1), the list was scrutinised to identify those dimensions that were supported by different researchers. The names attributed to the dimensions in each study served as guideline for identification. Nineteen dimensions emerged, namely Age, Atmosphere, Clientele, Convenience, Credit, Environment, Facilities, Institutional, Layout, Location, Merchandise, Posttransaction, Price, Promotional, Quality, Reputation, Sales personnel, Service and Value. These dimensions were refined to

- ensure that dimensions are grouped together appropriately;

- address any overlap between dimensions;

- eliminate any redundant dimensions; and

- determine the relevancy of the dimensions within the current study. 
TABLE 2

Store image subdimensions identified from the literature

\begin{tabular}{|c|c|c|c|}
\hline $\begin{array}{l}\text { IDENTIFIED } \\
\text { DIMENSIONS }\end{array}$ & $\begin{array}{l}\text { IDENTIFIED } \\
\text { SUBDIMENSIONS }\end{array}$ & IDENTIFIED SUBDIMENSIONS FROM LITERATURE & AUTHORS* \\
\hline \multirow[t]{4}{*}{ Atmosphere } & Décor & Colours; Décor; Neatness & Baker et al., 2002; Miranda et al., 2005 \\
\hline & Smell & Smell & Bosmans, 2006; Orth \& Bourrain, 2005 \\
\hline & Sound & Sound & Sweeney \& Wyber, 2002 \\
\hline & Store atmosphere & Size; Store atmosphere & Koo, 2003; Thang \& Tan, 2003 \\
\hline \multirow[t]{7}{*}{ Convenience } & Check-out & Check-out & Bielen \& Demoulin, 2007 \\
\hline & Travel & Duration of travel; Ease of travel & Ibrahim, 2002; Jin \& Kim, 2003 \\
\hline & Location & $\begin{array}{l}\text { Enclosed mall; Location; Location close to home; Location close to work; } \\
\text { Location near other clothing stores; Location near a variety of other } \\
\text { stores/facilities; Smoking policy }\end{array}$ & Miranda et al., 2005 \\
\hline & Parking & Parking & Stoltman et al., 1999 \\
\hline & Shopping ease & $\begin{array}{l}\text { Convenience; Labels/tags; Package carryout; Phone cards; Shopping } \\
\text { ease; Store accessibility; Store familiarity; Strong carry bags; Not } \\
\text { crowded }\end{array}$ & De Klerk \& Ampousah, 2000; Jin \& Kim, 2003 \\
\hline & Store hours & Store hours & Kaufman \& Lane, 1996 \\
\hline & Transportation & Transportation & Ibrahim, 2002; Jin \& Kim, 2003 \\
\hline \multirow[t]{5}{*}{ Facilities } & Store layout & Aisle placement; Spaciousness; Store layout & $\begin{array}{l}\text { Groeppel-Klein \& Bartman, 2007; Semeijn et al., } \\
\text { 2003; Miranda et al., } 2005\end{array}$ \\
\hline & Store appearance & Clean store; Entrance/exit; Outside appearance; Store maintenance & Richardson et al., 1996; Siu \& Cheung, 2001 \\
\hline & Facilities convenience & Family shopping; Refreshment within store; Rest area; Washrooms & Kerfoot et al., 2003; Paulins \& Geistfeld, 2003 \\
\hline & Fitting rooms & Fitting rooms & Kerfoot et al., 2003; Paulins \& Geistfeld, 2003 \\
\hline & Fixtures & $\begin{array}{l}\text { Floor covering; Hangers; Information boards; Lighting; Mirrors; Physical } \\
\text { facilities; Temperature }\end{array}$ & Kerfoot et al., 2003; Paulins \& Geistfeld, 2003 \\
\hline \multirow[t]{4}{*}{ Institutional } & Clientele & $\begin{array}{l}\text { Clientele; Communication; Discrimination; Friend association; Sales } \\
\text { personnel - clientele; Social class }\end{array}$ & Amirani \& Gates, 1993; Harris et al., 2000 \\
\hline & Overall impression & Overall impression & Ailawadi \& Keller, 2004; Alessandri, 2001 \\
\hline & Store reputation & Store reputation & Alessandri, 2001; Harris \& De Chernatony, 2001 \\
\hline & Store association & $\begin{array}{l}\text { Attractive service materials; Can identify with store; Self-image; Store } \\
\text { name }\end{array}$ & Ailawadi \& Keller, 2004; Harris \& De Chernatony, 2001 \\
\hline \multirow[t]{4}{*}{ Merchandise } & Merchandise assortment & $\begin{array}{l}\text { Labels/brands; Merchandise assortment; Merchandise availability; } \\
\text { Seasonal changes not too early; Unique merchandise; Variety within } \\
\text { store }\end{array}$ & Koo, 2003; Thang \& Tan, 2003 \\
\hline & Merchandise style & $\begin{array}{l}\text { Appropriate merchandise; Merchandise fashion; Specialised } \\
\text { merchandise }\end{array}$ & Taylor \& Cosenza, 2002 \\
\hline & Merchandise price & Merchandise price; Merchandise value & Moore \& Carpenter, 2006; Sullivan et al., 2002 \\
\hline & Merchandise quality & Dependable merchandise; Merchandise quality; Store quality & Babakus et al., 2004; Verma \& Gupta, 2004 \\
\hline \multirow[t]{3}{*}{ Promotion } & Advertising & Promotion; Advertising; Personal contact; Realistic models & Carroll et al., 2007; DuFrene et al., 2005 \\
\hline & Displays & Displays & Sen et al., 2002 \\
\hline & Sales incentives & Sales; Incentives; Special events & Dawes, 2004; Alvarez \& Casielles, 2005 \\
\hline \multirow[t]{2}{*}{ Sales personnel } & $\begin{array}{l}\text { Sales personnel } \\
\text { interaction }\end{array}$ & $\begin{array}{l}\text { Attention from sales personnel; Caring sales personnel; Competent } \\
\text { sales personnel; Courteous sales personnel; Friendly sales personnel; } \\
\text { Helpful sales personnel; Knowledgeable sales personnel; Professional } \\
\text { sales personnel; Sales personnel; Social interaction; Trust sales } \\
\text { personnel; Unobtrusive sales personnel }\end{array}$ & $\begin{array}{l}\text { Baker et al., 2002; Grace \& O’Cass, 2005; Hu \& } \\
\text { Jasper, } 2006\end{array}$ \\
\hline & $\begin{array}{l}\text { Sales personnel } \\
\text { appearance }\end{array}$ & $\begin{array}{l}\text { Appearance of sales personnel; Sales personnel similar to yourself; } \\
\text { Sales personnel your age; Sales personnel your gender }\end{array}$ & De Klerk et al., 1993 \\
\hline \multirow[t]{4}{*}{ Service } & After-sales service & $\begin{array}{l}\text { Alterations; Complaint handling; Post-transaction satisfaction; Return } \\
\text { policy }\end{array}$ & Maxham \& Netemeyer, 2003; Stauss, 2002 \\
\hline & Payment options & Bank card; Credit; Layaway; Payment options; Store card & Huddleston et al., 1990; Park \& Burns, 2005 \\
\hline & In-store service & $\begin{array}{l}\text { Appro facilities; Gift wrapping; Inter-store transfers; Number of sales } \\
\text { personnel; Packaging; Sales personnel advice; Sales personnel service; } \\
\text { Self-service; Service; Trolley/basket }\end{array}$ & Thang \& Tan, 2003; Teller et al., 2006 \\
\hline & Delivery options & Delivery options; Phone orders & Thang \& Tan, 2003 \\
\hline
\end{tabular}

* Only some of the most recent authors are listed here

This refining exercise resulted in the 19 dimensions being scaled down to eight dimensions as depicted in Table 1.

Similar to the diversity in dimensions underlying store image the subdimensions mentioned in the literature are also much varied. A composite list of subdimensions included within each dimension was compiled from the reviewed studies. The subdimensions were grouped together on the basis of name similarity and frequency of mentions recorded. However, the need to further refine the subdimensions for inclusion in a model 


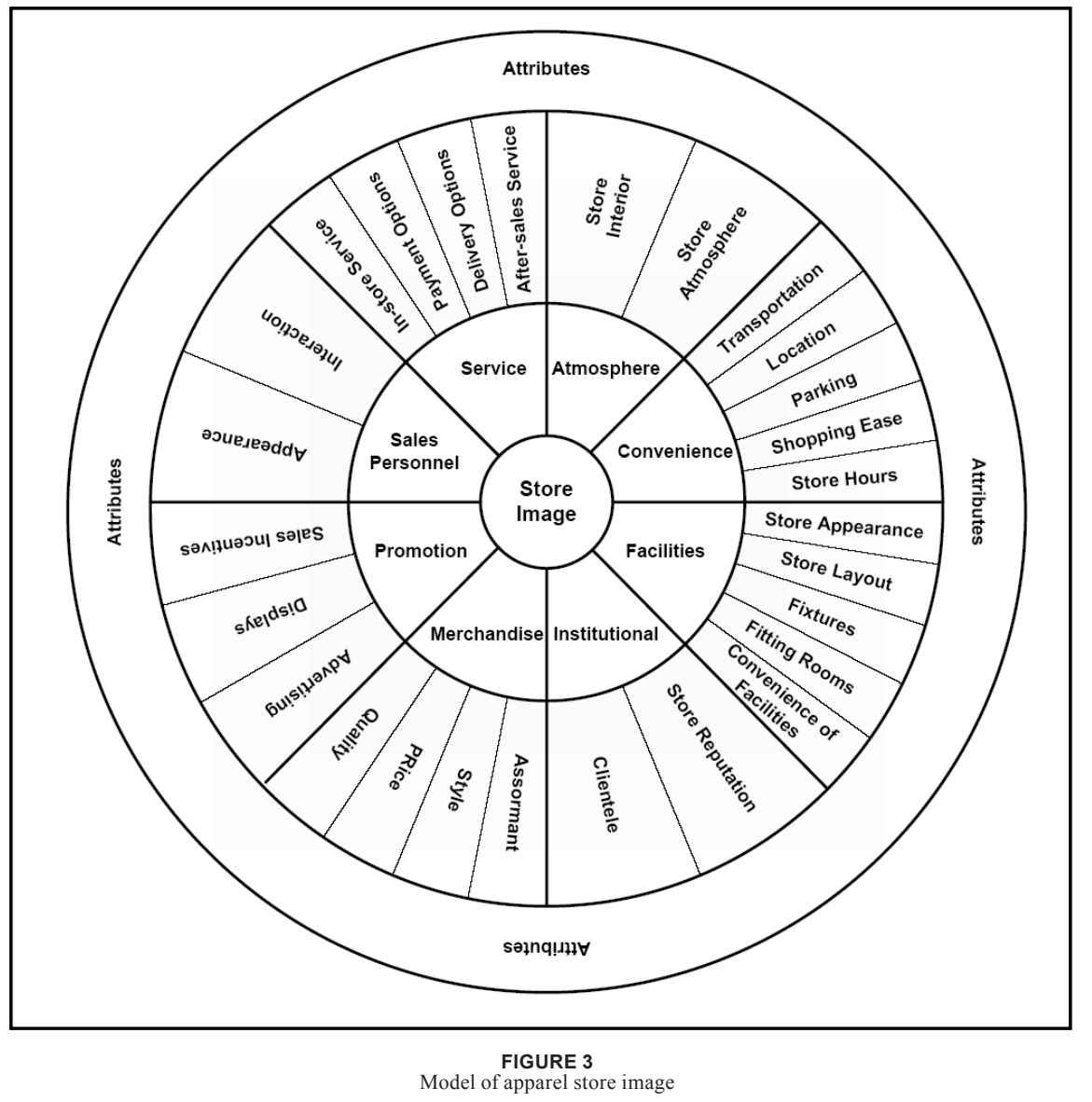

of the underlying structure of store image became evident. The possible overlap between subdimensions (within dimensions), the relevancy of each subdimension as well as the grouping of the final list of subdimensions was critically assessed. Table 2 depicts the dimensions and subdimensions identified as well as subdimensions referred to by various authors.

The multiplicity of consumer variables related to store image (refer to Figure 1), as well as the wide array of store attributes and subdimensions condensed into dimensions (refer to Table 2) are but some of the issues that should urge researchers to conduct investigations into store image with circumspection. Any endeavour to propose a definition and model of the underlying theoretical structure of store image should take cognisance of not only these issues but especially the gestalt nature of store image.

\section{CONCLUSION: PROPOSED MODEL AND DEFINITION OF STORE IMAGE}

In the proposed model, the four concentric circles represent a mutual influence on each other. Central to the model is store image. The eight dimensions underpinning the construct are represented in the first concentric circle, followed by the subdimensions underlying each dimension. The outer concentric circle of the model constitutes the specific store attributes underlying the identified subdimensions and dimensions. The perception of these store attributes is integral to store image formation. The size and components of each circle are not related to the importance of the specific dimension or subdimension. This model serves to delineate the underlying structure of the store image construct and should be implemented as a starting point when developing instruments to measure store image.
The proposed conceptual model of the underlying theoretical structure of store image was submitted for expert judging to further enhance the accuracy and comprehensiveness thereof. Firstly, the model was considered at a special advisory session with two experts in the field of store image and consumer behaviour. Since the model was used as a point of departure for item generation and the subsequent development of a store image scale (refer to Part 2 of this series), it was imperative to ensure that the model represented a logical and practical framework. The review of the model was done in conjunction with a review of the initial item pool. From the feedback of this session, several adaptations were made to the model, specifically to the wording, ordering and grouping of the subdimensions within each dimension. Secondly, the model was submitted to a panel of experts from different but related fields of study, all of whom were familiar with the research problem, study objectives and scale development (three $\mathrm{PhD}$ holders and one advanced PhD candidate). From the feedback one change was effected, namely the grouping of Smell and Sound under the subdimension Store interior within the Atmosphere dimension.

The revised model is presented in Figure 3 (from here onwards referred to as the model of apparel store image).

Due to the nature and scope of store image, the formulation of a succinct definition is extremely difficult. The risk remains that important facets and nuances could be omitted resulting in a deficient definition. Thus,

store image is defined as a complex, multidimensional construct based on the perception of tangible and intangible store attributes associated with eight dimensions, namely Atmosphere, Convenience, Facilities, Institutional, Merchandise, Promotion, Sales personnel and Service. These dimensions are further delineated into subdimensions that are underpinned by specific store attributes. Store image has a gestalt nature that is represented by the interaction 
between the salient tangible and intangible store attributes. The formation of store image relies on the perception of a store, which varies by retailer, product and target market. By implication, store image is influenced by (1) the consumer's perception of a set of salient store attributes; (2) the importance the consumer places on the various store image dimensions, subdimensions and the associated store attributes; as well as (3) the retailer's manipulation of these store attributes through strategic management.

Store image is a complex construct. The investigation of existing literature reported in this article culminated in a proposed model and comprehensive definition of store image that could be refined and tested further. This definition and the proposed model of apparel store image served as the point of departure for the next phases in the scale development process that will be reported in parts 2 and 3 of this article series.

\section{REFERENCES}

Abratt, R. (1989). A new approach to the corporate image management process. Journal of Marketing Management, 5(1), 63-76.

Ailawadi, K.L. \& Keller, K.L. (2004). Understanding of retail branding: conceptual insights and research priorities. Journal of Retailing, 80(4), 331-342.

Ajzen, I. (1988). Attitudes, personality, and behaviour. Chicago: Dorsey Press.

Ajzen, I. \& Fishbein, M. (2004). The influence of attitudes on behaviour. In D. Albaraccin, B.T. Johnson \& M.P. Zunna (Eds.), Handbook of attitudes and attitude change: basic principles. Mahwah: Erlbaum

Alessandri, S.W. (2001). Modeling corporate identity: a concept explication and theoretical explanation. Corporate Communications: An International Journal, 6(4), 173-182.

Alvarez, B.A. \& Casielles, R.V. (2005). Consumer evaluations of sales promotion: the effect on brand choice. European Journal of Marketing, 39(1/2), 54-70.

Amine, A. \& Cadenat, S. (2003). Efficient retailer assortment: a consumer choice evaluation perspective. International Journal of Retail and Distribution Management, 31(10), 486-497.

Amirani, S. \& Gates, R. (1993). An attribute-anchored conjoint approach to measuring store image. International Journal of Retail and Distribution Management, 21(5), 30-39.

Assael, H. (1992). Consumer behavior and marketing action (4th Ed.) Boston: PWS-Kent.

Babakus, E., Bienstock, C.C. \& Van Scotter, J.R. (2004). Linking perceived quality and customer satisfaction to store traffic and revenue growth. Decision Sciences, 35(4), 713-737.

Baker, J., Parasuraman, A., Grewal, D. \& Voss, G.B. (2002). The influence of multiple store environment cues on perceived merchandise value and patronage intentions. Journal of Marketing, 66(2), 120-141

Bellenger, D.N., Robertson, D.H. \& Greenberg, B.A. (1977) Shopping center patronage motives. Journal of Retailing, 53(2), 29-38

Bellizzi, J.S., Crowley, A.E. \& Hasty, R.W. (1983). The effects of color in store design. Journal of Retailing, 59(1), 21-45.

Bielen, F. \& Demoulin, N. (2007). Waiting time influence on the satisfaction-loyalty relationship in services. Managing Service Quality, 17(2), 174-193.

Bloemer, J. \& De Ruyter, K. (1998). On the relationship between store image, store satisfaction and store loyalty. European Journal of Marketing, 32(5/6), 499-513.

Bosmans, A. (2006). Scents and sensibility: when do (in)congruent ambient scents influence product evaluations? Journal of Marketing, 70, 32-43.

Burns, D.J. (1992). Image transference and retail site selection. International Journal of Retail and Distribution Management, 20(5), 38-43

Carroll, A., Barnes, S.J., Scornavacca, E. \& Fletcher, K. (2007) Consumer perceptions and attitudes towards SMS advertising: recent evidence from New Zealand. International Journal of Advertising, 26(1), 79-98.

Cary, R.T. \& Zylla, J.M. (1981). Fabric specialty stores: consumer dissatisfaction with selected in-store attributes. Journal of Consumer Studies and Home Economics, 5, 69-78.

Chang, C. \& Tu, C. (2005). Exploring store image, customer satisfaction and customer loyalty relationship: evidence from Taiwanese hypermarket industry. The Journal of American Academy of Business, Cambridge, 7(2), 197-202.

Chowdhary, U. (1999). Retail store attributes, fashion leadership and older consumers. Journal of Fashion Marketing and Management, 3(2), 126-132.

Chowdhary, J., Reardon, J. \& Srivastava, R. (1998). Alternative modes of measuring store image: an empirical assessment of structures versus unstructured measures. Journal of Marketing Theory and Practice, 6(2), 72-86.

Collins-Dodd, C. \& Lindley, T. (2003). Store brands and retail differentiation: the influence of store image and store brand attitude on store own brand perceptions. Journal of Retailing and Consumer Services, 10(6), 345-352.

Dawes, J. (2004). Assessing the impact of a very successful price promotion on brand, category and competitor sales. Journal of Product and Brand Management, 13(5), 303-314.

De Klerk, H.M. \& Ampousah, L. (2002). The physically disabled South African female consumer's problems in purchasing clothing. International Journal of Consumer Studies, 26(2), 93-101.

De Klerk, H.M., Velleman, A.K. \& Malherbe, E. (1993). 'n Kwalitatiewe ondersoek na die invloed van aspekte van die klerewinkel en die verkoopsdame se voorkoms op die damesklere-verbruiker se besluitnemingsproses. Journal of Family Ecology and Consumer Sciences, 26(1), 15-26.

DeVellis, R.F. (2003). Scale development: theory and applications (2nd Ed.). Thousand Oaks: Sage Publications.

Dichter, E. (1985). What's in an image. Journal of Marketing, 2(1) $75-81$.

Donovan, R.J. \& Rossiter, J.R. (1982). Store atmosphere: an environmental psychology approach. Journal of Retailing, $58(1), 34-57$.

Dowling, G. (1986). Managing your corporate images. Industrial Marketing Management, 15, 109-115.

DuFrene, D.D., Engelland, B.T., Lehman, C.M. \& Pearson, R.A. (2005). Changes in consumer attitudes resulting from participation in a permission e-mail campaign. Journal of Current Issues and Research in Advertising, 27(1), 65-77.

Erdem, O., Oumlil, A.B. \& Tuncalp, S. (1999). Consumer values and the importance of store attributes. International Journal of Retail and Distribution Management, 27(4), 137-144.

Faircloth, J.B., Capella, L.M. \& Alford, B.L. (2001). The effect of brand attitude and brand image on brand equity. Journal of Marketing Theory and Practice, 9(3), 61-75.

Gehrt, K.C. \& Yan, R. (2004). Situational, consumer, and retailer factors affecting Internet, catalog, and store shopping. International Journal of Retail and Distribution Management, 32(1), 5-18.

Gómez, M.I., McLaughlin, E.W. \& Wittink, D.R. (2003). Do changes in customer satisfaction lead to changes in sales performance in food retailing? Working paper, Yale School of Management, New Haven.

Grace, D. \& O'Cass, A. (2005). An examination of the antecedents of repatronage intentions across different store formats. Journal of Retailing and Consumer Services, 12(4), 227-243.

Graeff, T.R. (1996). Using promotional messages to manage the effects of brand and self-image on brand evaluations. Journal of Consumer Marketing, 13(3), 4-18.

Groeppel-Klein, A. \& Bartmann, B. (2007). Anti-clockwise or clockwise? The impact of store layout on the process of orientation in a discount store. Paper presented at the European Conference of the Association for Consumer Research, 11-14 July, Milan, Italy.

Grossbart, S., Hampton, R., Rammohan, B. \& Lapidus, R.S. (1990). Environmental dispositions and customer response 
to store atmospherics. Journal of Business Research, 21(3), 225-241.

Hair, J.F., Black, W.C., Babin, B.J., Anderson, R.E. \& Tatham, R.L. (2006). Multivariate data analysis (6th Ed.). Upper Saddle River: Pearson/Prentice Hall.

Harris, K., Baron, S. \& Parker, C. (2000). Understanding the consumer experience: it's 'good to talk'. Journal of Marketing Management, 16, 111-127.

Harris, F. \& De Chernatony, L. (2001). Corporate branding and corporate brand performance. European Journal of Marketing, $35(3 / 4), 441-456$

Hu, H. \& Jasper, C.R. (2006). Social cues in the store environment and their impact on store image. International Journal of Retail and Distribution Management, 34(1), 25-18.

Huddleston, P., Ford, I. \& Mahoney, M.Y. (1990). The relationship between importance of retail store attributes and lifestyle of mature female consumers. Journal of Consumer Studies and Home Economics, 14, 71-85.

Hogg, M.K., Cox, A.J. \& Keeling, K. (2000). The impact of self-monitoring on image congruence and product/brand evaluation. European Journal of Marketing, 34(5/6), 641-666.

Hyllegard, K., Eckman, M., Descals, A.M. \& Borja, M.A.G. (2005). Spanish consumers' perceptions of US apparel speciality retailers' products and services. Journal of Consumer Behaviour, 4(5), 345-362.

Ibrahim, M.F. (2002). Disaggregating the travel components in shopping centre choice; an agenda for valuation practices. Journal of Property Investment and Finance, 20(3), 277-294.

Jamal, A. \& Goode, M.M.H. (2001). Consumers and brands: a study of the impact of self-image congruence on brand preference and satisfaction. Marketing Intelligence and Planning, 19(7), 482-492.

James, D.L., Durand, R.M. \& Dreves, R.A. (1976). The use of a multi-attribute attitude model in a store image study. Journal of Retailing, 52(2), 23-32.

Janse van Noordwyk, H.S. (2002). Perceived importance of retail store image attributes to the female large-size apparel consumer in a multicultural society. Unpublished master's thesis, Stellenbosch University, Stellenbosch.

Jin, B. \& Kim, J. (2003). A typology of Korean discount shoppers: shopping motives, store attributes, and outcomes. International Journal of Service Industry Management, 14(4), 396-419.

Joyce, M.L. \& Lambert, D.R. (1996). Memories of the way stores were and retail store image. International Journal of Retail and Distribution Management, 24(1), 24-33.

Kaufman, C.F. \& Lane, P.M. (1996). A new look at one-stop shopping: a TIMES model approach to matching store hours and shopper schedules. Journal of Consumer Marketing, 13(1), $4-25$.

Keaveney, S.M. \& Hunt, A.H. (1992). Conceptualization and operationalisation of retail store image: a case of rival middle-level theories. Journal of Academy of Marketing Science, 20(2), 165-175.

Kennedy, S. (1977). Nurturing corporate images. European Journal of Marketing, 11(3), 120-164.

Kerfoot, S., Davies, B. \& Ward, P. (2003). Visual merchandising and the creation of discernible retail brands. International Journal of Retail and Distribution Management, 31(3), 143-152.

Kim, Y. \& Han, S. (2000). Perceived images of retail stores and brands: comparison among three ethnic consumer groups. Journal of Family and Consumer Sciences, 92(3), 58-61.

Kim, J.O. \& Jin, B. (2001). Korean consumers' patronage of discount stores: domestic vs. multinational discount store shoppers' profiles. Journal of Consumer Marketing, 18(3), 236-255.

Kliatchko, J. (2005). Towards a new definition of Integrated Marketing Communications (IMC). International Journal of Advertising, 24(1), 7-34.

Ko, E. \& Kincade, D.H. (1997). The impact of quick response technologies on retail store attributes. International Journal of Retail and Distribution Management, 25(2/3), 90-99.
Koo, D. (2003). Inter-relationships among store images, store satisfaction, and store loyalty among Korea Discount Retail patrons. Asia Pacific Journal of Marketing and Logistics, 15(4), 42-71.

Kotler, P. (1973-1974). Atmospherics as a marketing tool. Journal of Retailing, 49(4), 48-55.

Lee, M. \& Johnson, K.K.P. (1997). Customer expectations for service at apparel retail outlets. Journal of Family and Consumer Sciences, Winter, 26-30.

Lindquist, J.D. (1974-1975). Meaning of image. Journal of Retailing, 50(4), 29-38.

Lumpkin, J.R., Greenberg, B.A. \& Goldstucker, J.L. (1985). Marketplace needs of the elderly: determinant attributes and store choice. Journal of Retailing, 61(2), 75-105.

Manolis, C., Keep, W.W., Joyce, M.L. \& Lambert, D.R. (1994). Testing the underlying structure of store image scale. Educational and Psychological Measurement, 54(3), 628-645.

Marks, R.B. (1976). Operationalizing the concept of store image. Journal of Retailing, 52(3), 37-46.

Markwick, N. \& Fill, C. (1997). Towards a framework for managing corporate identity. European Journal of Marketing, 31(5/6), 396-409.

Martineau, P. (1958). The personality of the retail store. Harvard Business Review, 36, 47-55.

Mattson, B.E. (1982). Situational influences on store choice. Journal of Retailing, 58(3), 46-58.

Maxham, J.G. \& Netemeyer, R.G. (2003). Firms reap what they sow: the effects of shared values and perceived organizational justice on customers' evaluations of complaint handling. Journal of Marketing, 67, 46-62.

Miranda, M.J., Kónja, L. \& Havrila, I. (2005). Shoppers' satisfaction levels are not the only key to store loyalty. Marketing Intelligence and Planning, 23(2), 220-232.

Mitchell, V.W. \& Kiral, R.H. (1998). Primary and secondary store-loyal customer perceptions of grocery retailers. British Food Journal, 100(7), 312-319.

Moore, M. \& Carpenter, J. (2006). The effect of price as a marketplace cue on retail patronage. Journal of Product and and Brand Management, 15(4), 265-271.

Morschett, D., Swoboda, B. \& Foscht, T. (2005). Perception of store attributes and overall attitude towards grocery retailers: the role of shopping motives. International Review of Retail, Distribution and Consumer Research, 15(4), 423-447.

Moye, L.N. \& Giddings, V.L. (2002). An examination of the retail approach-avoidance behavior of apparel consumers. Journal of Fashion Marketing and Management, 6(3), 259-276.

Moye, L.N. \& Kincade, D.H. (2002). Influence of usage situations and consumer shopping orientations on the importance of retail store environment. International Review of Retail, Distribution and Consumer Research, 12(1), 59-79.

Netemeyer, R.G., Bearden, W.O. \& Sharma, S. (2003). Scaling procedures: issues and applications. Thousand Oaks: Sage Publications.

Newberry, C.R., Klemz, B.R. \& Boshoff, C. (2003). Managerial implications of predicting purchase behaviour from purchase intentions: a retail patronage case study. Journal of Services Marketing, 17(6), 609-620.

Oates, B., Shufeldt, L. \& Vaught, B. (1996). A psychographic study of the elderly and retail store attributes. Journal of Consumer Marketing, 13(6), 14-27.

Odekerken-Schröder, G., De Wulf, K., Kasper, H., Kleijnen, M., Hoekstra, J. \& Commandeur, H. (2001). The impact of quality on store loyalty: a contingency approach. Total Quality Management, 12(3), 307-322.

Orth, U.R. \& Bourrain, A. (2005). Ambient scent and consumer exploratory behaviour: a causal analysis. Journal of Wine Research, 16(2), 137-150.

Osman, M.Z. (1993). A conceptual model of retail image influences on loyalty patronage behaviour. The International Review of Retail, Distribution and Consumer Research, 3(2), $133-148$. 
Oxenfeldt, A.R. (1974-1975). Developing a favorable pricequality image. Journal of Retailing, 50(4), 108-115.

Park, H. \& Burns, L.D. (2005). Fashion orientation, credit card use, and compulsive buying. Journal of Consumer Marketing, 22(3), 135-141.

Paulins, V.A. \& Geistfeld, L.V. (2003). The effect of consumer perceptions of store attributes on apparel store preference. Journal of Fashion Marketing and Management, 7(4), 371-385.

Porter, S.S. \& Claycomb, C. (1997). The influence of brand recognition on retail store image. Journal of Product and Brand Management, 6(6), 373-387.

Quester, P.G., Karunaratna, A. \& Goh, L.K. (2000). Self-congruity and product evaluation: a cross-cultural study. Journal of Consumer Marketing, 17(6), 525-537.

Richardson, P., Jain, A.K. \& Dick, A. (1996). The influence of store aesthetics on evaluation of private label brands. Journal of Product and Brand Management, 5(1), 19-28.

Semeijn, J., Van Riel, C.R. \& Ambrosini, A.B. (2003). Consumer evaluations of store brands: effects of store image and product attributes. Journal of Retailing and Consumer Services, 11, 247-258.

Sen, S., Block, L.G. \& Chandran, S. (2002). Window displays and consumer shopping decisions. Journal of Retailing and Consumer Services, 9(5), 277-290.

Shim, S. \& Kotsiopulos, A. (1992). Patronage behavior of apparel shopping: part II. Testing a patronage model of consumer behavior. Clothing and Textiles Research Journal, 10(2), 58-64.

Shim, S., Kotsiopulos, A. \& Knoll, D.S. (1990). Short, averageheight, tall, and big men: body-cathexis, clothing and retail satisfactions, and clothing behaviour. Perceptual and Motor Skills, 70, 83-96.

Siu, N.Y.M. \& Cheung, J.T. (2001). A measure of retail service quality. Marketing Intelligence and Planning, 19(2), 88-96.

Solgaard, H.S. \& Hansen, T. (2003). A hierarchical Bayes model of choice between supermarket formats. Journal of Retailing and Consumer Services, 10, 169-180.

Solomon, M.R. (2002). Consumer behavior; buying, having and being (5th Ed.). Upper Saddle River, New Jersey: Prentice Hall International, Inc.

Stauss, B. (2002). The dimensions of complaint satisfaction: process and outcome complaint satisfaction versus cold act and warm act complaint satisfaction. Managing Service Quality, 12(3), 173-183.

Stern, B., Zinkhan, G.M. \& Jaju, A. (2001). Marketing images; construct definition, measurement issues, and theory development. Marketing Images, 1(2), 201-224.

Stoltman, J.J., Morgan, F.W. \& Anglin, L.K. (1999). An investigation of retail shopping situations. International Journal of Retail and Distribution Management, 27(4), 145-152.

Stuart, H. (1999). Towards a definitive model of the corporate identity management process. Corporate Communications: An International Journal, 4(4), 200-207.

Sullivan, P., Savitt, R., Zheng, Y. \& Cui, Y. (2002). Rural shoppers: who gets their apparel dollars? Journal of Fashion Marketing and Management, 6(4), 363-380.
Sweeney, J.C. \& Wyber, F. (2002). The role of cognitions and emotions in the music-approach avoidance- behaviour relationship. Journal of Services Marketing 16(1), 51-69.

Taylor, S.L. \& Cosenza, R.M. (2002). Profiling later aged female teens: mall shopping behaviour and clothing choice. Journal of Consumer Marketing, 19(5), 393-408.

Teller, C., Kotzab, H. \& Grant, D.B. (2006). The consumer direct services revolution in grocery retailing: an exploratory investigation. Managing Service Quality, 16(1), 78-96.

Terblanché, N. (1998). Retail management. Johannesburg: International Thomson Publishing.

Terblanché, N.S. \& Boshoff, C. (2004). The in-store shopping experience: a comparative study of supermarket and clothing store customers. South African Journal of Business Management, 35(4), 1-9.

Thang, D.C.L. \& Tan, B.L.B. (2003). Linking consumer perception to preference of retail stores: an empirical assessment of the multi-attributes of store image. Journal of Retailing and Consumer Services, 10, 193-200.

Thompson, K.E. \& Chen, Y.L. (1998). Retail store image: a meansend approach. Journal of Marketing Practice, 4(6), 161-173.

Van de Velde, J., Pelton, W., Turnbull Caton, S. \& Byrne, M. (1996). Consumer behaviour reflected in store and clothing selection criteria: a pilot study in Canada and England. Journal of Consumer Studies and Home Economics, 20(4), 377-391.

Van Kenhove, P., De Wulf, K. \& Van Waterschoot, W. (1999). The impact of task definition on store-attribute saliences and store choice. Journal of Retailing, 75(1), 125-137.

Varley, R. (2005). Store image as the key differentiator. European Retail Digest, 46, 18-21.

Verma, D.P.S. \& Gupta, S.S. (2004). Does higher price signal better quality? Vikalpa, 29(2), 67-77.

Visser, E.M. \& Du Preez, R. (2001). Apparel shopping orientation: two decades of research. Journal of Family Ecology and Consumer Sciences, 29, 72-81.

Visser, E.M., Du Preez, R. \& Janse van Noordwyk, H.S. (2006). Importance of apparel store image attributes: perceptions of female consumers. SA Journal of Industrial Psychology, 32(3) 49-62.

Ward, J.C., Bitner, M.J. \& Barnes, J. (1992). Measuring the prototypicality and meaning of retail environments. Journal of Retailing, 68(2), 194-220.

Williams, T.G. \& Slama, M.E. (1995). Market mavens' purchase decision evaluative criteria: implications for brand and store promotion efforts. Journal of Consumer Marketing, 12(3), 4-21.

Wong, J.K. \& Teas, R.K. (2001). A test of the stability of retail store image mapping based on multi-entity scaling data. Journal of Retailing and Consumer Services, 8, 61-70.

Wong, G.K.M. \& Yu, L. (2003). Consumers' perception of store image of joint venture shopping centres: first-tier versus second-tier cities in China. Journal of Retailing and Consumer Services, 10, 61-70.

Zimmer, M.R., \& Golden, L.L. (1988). Impressions of retail stores: a content analysis of consumer images. Journal of Retailing, 64(3), 265-293. 